dr hab. inż. Marian Medwid

Instytut Pojazdów Szynowych „,TABOR”

mgr in:. Rafat Cichy

Instytut Pojazdów Szynowych ,TABOR”

\title{
Koncepcja wykorzystania techniki bimodalnej transportu do budowy dróg i autostrad
}

\begin{abstract}
$W$ artykule przedstawiono propozycję wykorzystania bimodalnego systemu transportowego do dowozu materiatów na tereny budowy autostrad $i$ dróg szybkiego ruchu. Zaprezentowano uktad biegowy taboru bimodalnego oraz jednostki tadunkowe przystosowane do przewozu cementu, kruszywa i asfaltu. Zaproponowano organizacje dostaw materiatów systemem bimodalnym, na zasadzie tworzenia „wędrujacego terminalu" wzdluż trasy budowy autostrady.

(Materiat do artykulu przedstawiono $w$ formie prezentacji na Międzynarodowych Targach Poznańskich - Transporta 2009 - Transport Szynowy XXI wieku dla Polski.)
\end{abstract}

\section{Wstęp}

Jednym z podstawowych problemów, co podkreślają eksperci [1], obok jakości dostarczanych materialów, jest ich dostawa na teren budowy autostrad. Obecnie odbywa się to głównie za pomocą transportu drogowego. Transport ten okazuje się w praktyce niewydolny $\mathrm{z}$ powodu braku odpowiedniej infrastruktury drogowej, niszczenia istniejących dróg i środowiska naturalnego oraz czasowego spiętrzenia realizacji zamówień na dostawę dużych ilości materiałów. Drogi powiatowe, po których poruszają się ciężkie samochody transportujące materiały budowlane, często przez pół polski, przeznaczone są do przejazdu samochodów o nacisku do 8 ton na oś. Dopuszczony przepisami maksymalny nacisk osi dla pojazdów ciężarowych wynosi 11 ton/oś. Coraz częściej można usłyszeć powiedzenie: „największym wrogiem budowy dróg jest brak dróg po których można by dostarczyć materiały". Najszybszy i najbardziej opłacalny transport kolejowy obecnie dostarcza zaledwie $10 \%$ materiałów do budowy autostrad. Według różnych źródeł na budowę $1 \mathrm{~km}$ autostrad potrzeba od 30 tyś nawet do 100 tyś ton kruszywa [2,3]. Jako podstawowe wady przewozu materiałów koleją wymienia się: wysokie stawki za użytkowanie linii kolejowych, oraz to, że linie kolejowe nie leżą w bezpośrednim sąsiedztwie budowanych autostrad [3,4]. W transporcie drogowym nie uwzględnia się kosztów zewnętrznych takich jak: ochrona środowiska, degradacja dróg, zanieczyszczenie powietrza, hałas czy kongestia (zatory drogowe), które omówiono w [5]. Brakuje odpowiednich (kompleksowych) działań rządu doprowadzających do poprawienia konkurencyjności przewozów, w różnych gałęziach transportu, zwłaszcza drogowego i kolejowego.
Innowacyjna technologia transportu bimodalnego może być efektywnie wykorzystana szczególnie tam gdzie jest zapotrzebowanie dostaw towarów o odpowiednio dużym wolumenie strumieni transportowych ładunku. Jeden z przykładów możliwego wykorzystania techniki bimodalnej do zaopatrywania w paliwa stacji paliwowych w aglomeracjach miejskich przedstawiono w pracy [6], gdzie opisano również korzyści z zastosowanej techniki transportowej. Budowa autostrad i dróg szybkiego ruchu wymaga również dostarczenia na plac budowy dużych ilości materiałów budowlanych takich jak kruszywa, piasek, cement, asfalt.

Tempo budowy wynika między innymi z organizacji dostaw materiałów na miejsce prowadzonych robót.

Wybór metody logistycznej dostarczania materiałów budowlanych w odpowiedniej ilości w wymaganym czasie decyduje nie tylko o tempie realizacji prac budowlanych, ale może mieć istotny wpływ na koszt prowadzenia procesu inwestycyjnego.

W dalszej części opracowania przedstawiono opis systemu transportu bimodalnego przystosowanego do ruchu ,S" i ,SS" $\left(\mathrm{V}_{\max }=100 \mathrm{~km} / \mathrm{h}\right.$ przy nacisku osi $225 \mathrm{KN} \mathrm{V}$ max $=120 \mathrm{~km} / \mathrm{h}$ przy nacisku osi $200 \mathrm{KN}$ ) złożonego $\mathrm{z}$ bimodalnych jednostek ładunkowych przeznaczonych do przewozu podstawowych materiałów budowlanych niezbędnych do budowy autostrad i dróg ekspresowych.

\section{Uklad biegowy taboru bimodalnego}

Na rys. 1 pokazano skład bimodalny złożony $\mathrm{z}$ wózków końcowych 1 , wózków środkowych 2 , naczepy do przewozu asfaltu 3 , naczepy do przewozu cementu 4 oraz naczepy do transportu materiałów sypkich 5 (piasek, kruszywa). 


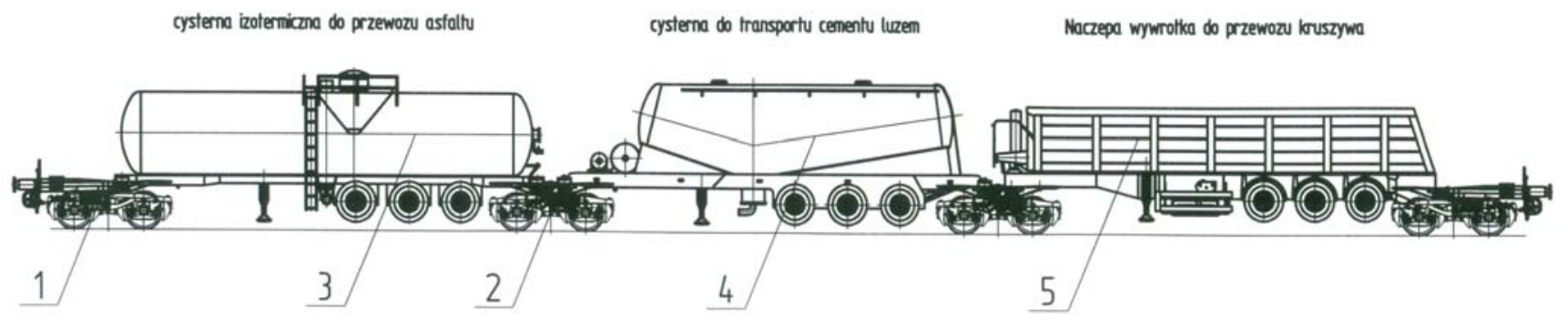

Rys. 1. Zestaw naczep bimodalnych w uformowaniu kolejowym
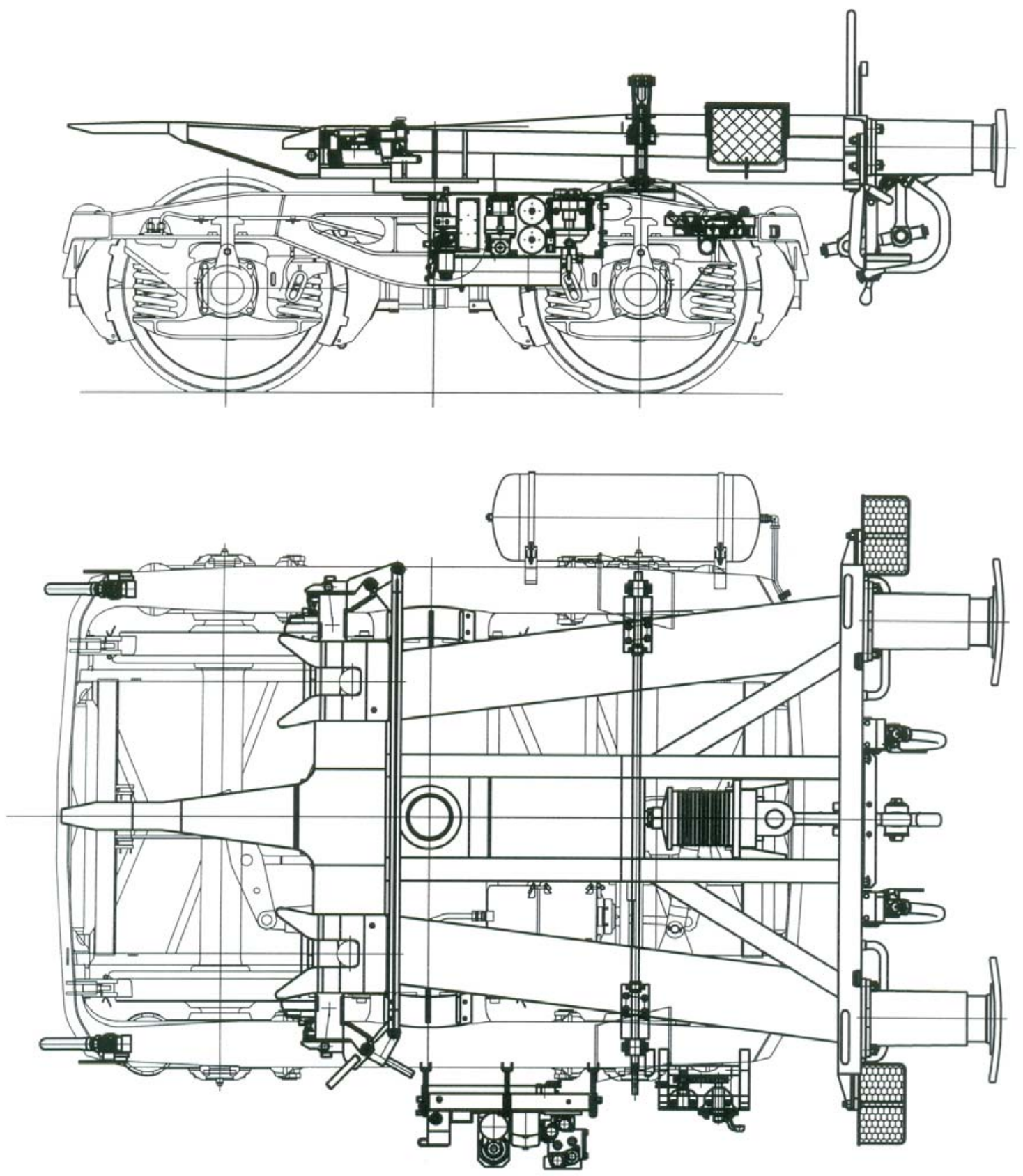

Rys. 2. Wózek końcowy

Układ biegowy pociągu bimodalnego stanowią wózki końcowe i wózki środkowe wyposażone w odpowiednie urządzenia zwane adapterami służącymi do posadowienia i połączenia naczep z wózkami kolejowymi.
Wózek końcowy rys. 2 to wózek opracowany na bazie standardowego wózka towarowego Y25 wyposażony w kompletny układ hamulcowy z cylindrem hamulcowym zbiornikiem powietrza oraz tablica pneumatyczną w której umieszczono zespół urządzeń sterujących pracą hamulca. 

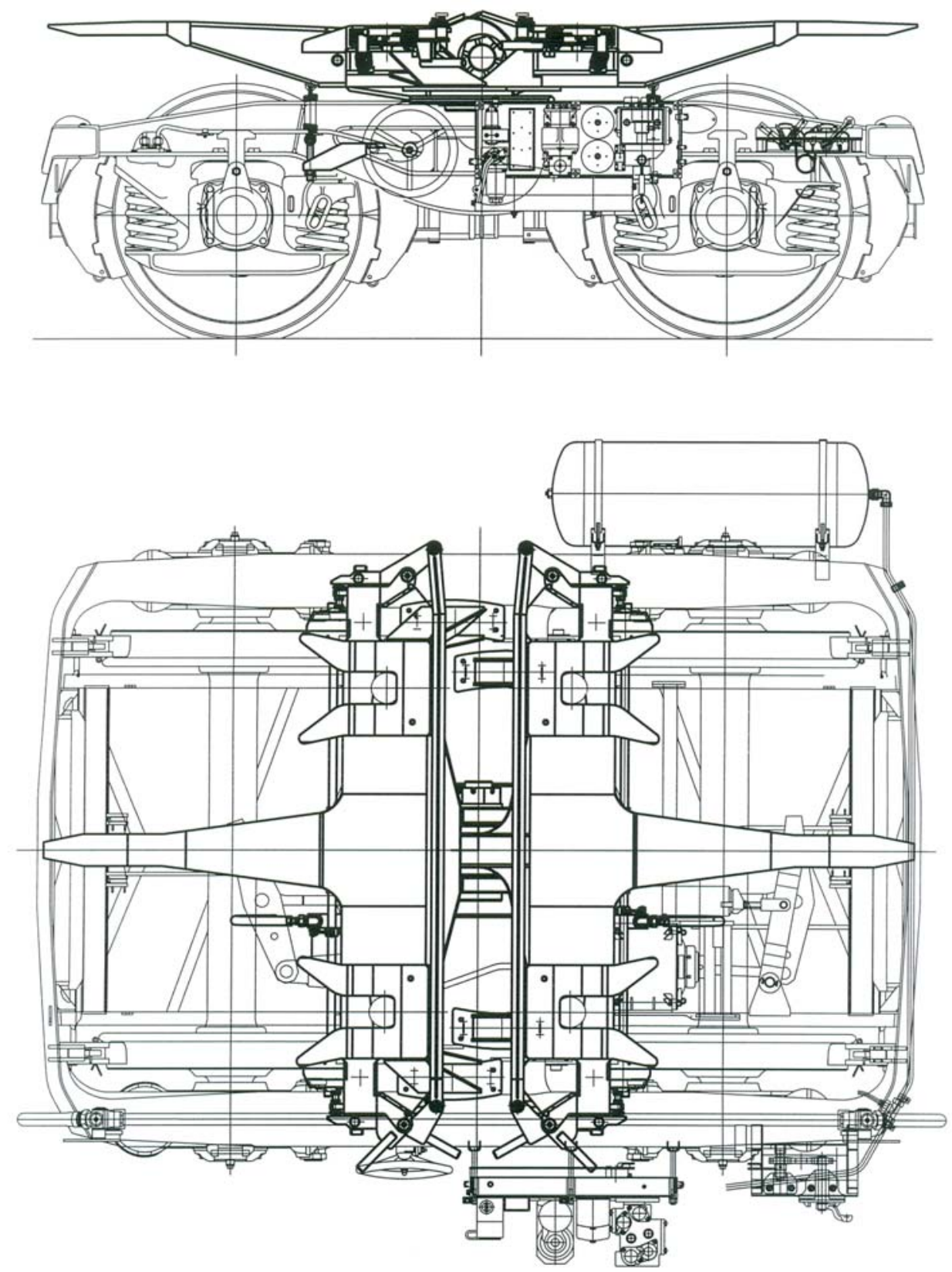

Rys. 3. Wózek środkowy

Adapter wózka końcowego zamocowano na wózku w konwencjonalny sposób tzn. za pomocą czopa skrętu oraz dwóch sprężystych ślizgów bocznych. W stanie swobodnym (bez naczepy) adapter opiera się dodatkowo na ramie wózka na odpowiednich podporach zapewniających wypoziomowanie pozycji adaptera względem wózka. Po montażu naczepy na adapterze podpory zostają uniesione. Adapter wózka końcowego można podzielić na dwa zespoły. Zespół przeznaczony do zamocowania naczepy na adapterze oraz zespół ramowy do połączenia adaptera $\mathrm{z}$ lokomotywą lub innym składem wagonów. Wózek środkowy rys. 3 wyposażono w kompletny układ hamulcowy podobnie jak wózek końcowy. Adapter wózka środkowego to dwuczęściową symetryczna konstrukcja belkowa o konstrukcji skrzynkowej połączona między sobą za pomocą standardowego przegubu kulistego. Dwuczęściowy adapter środkowy spoczywa na czopie skrętu wózka oraz czterech sprężystych ślizgach bocznych, po dwa ślizgi związane z jedną połową adaptera.

Każda połowa adaptera została wyposażona w siodła na których spoczywa koniec ramy naczepy $\mathrm{z}$ czopami sprzęgowymi oraz $\mathrm{w}$ urządzenia ryglujące do zamocowania czopów naczepy na adapterze. Belki poprzeczne każdej połowy adaptera maja podłużne belki, z końcówką naprowadzającą naczepę na adapter, w procesie łączenia naczepy $\mathrm{z}$ adapterem.

\section{Bimodalne jednostki ladunkowe}

Bimodalne jednostki ładunkowe różnią się od standardowych naczep drogowych przede wszystkim budową ramy nośnej oraz dodatkowym wyposażeniem wymaganym w ruchu kolejowym. Konstrukcja ramy nośnej winna zapewnić przeniesienie sił działa- 
jących na zestaw naczep bimodalnych w uformowaniu kolejowym, a końce ramy naczepy, zamocowanie naczepy na adapterach wózków kolejowych.

Drogowy układ jezdny należy wyposażyć w miechy nośne o zmiennej wysokości, pozwalającej na uniesienie tyłu ramy naczepy podczas najazdu naczepy na adapter, a następnie uniesienie osi drogowych (po połączeniu naczepy $\mathrm{z}$ adapterem) na wysokość wymaganą do „wyjścia” kół drogowych ze skrajni kolejowej. Do unoszenia osi drogowych służą dodatkowe miechy pneumatyczne oraz układ dźwigniowy, który po napełnieniu miechów, unosi osie drogowe. Po uniesieniu osi drogowych, osie są ryglowane za pomocą dźwigni hakowych sterowanych siłownikami pneumatycznymi, a następnie zabezpieczone mechanicznie przed samoczynnym odryglowaniem podczas jazdy po torze kolejowym.
Kolejną cechą konstrukcyjną odróżniającą naczepę standardową od bimodalnej jest odchylny zderzak, którego działanie można rozwiązać dwojako: odchylać zderzak pod ramą naczepy lub unosić na zawiasie obrotowym tak aby zderzak przyjął pozycję pionową nad końcem ramy naczepy.

Naczepa bimodalna jest również wyposażona w główny przewód hamulca kolejowego zakończony wężami gumowymi z główkami sprzęgu hamulcowego.

\subsection{Naczepy do przewozu cementu luzem}

$\mathrm{Na}$ rysunku 4 pokazano rozwiązania koncepcyjne dwóch wariantów konstrukcji naczepy bimodalnej do transportu cementu opracowanych $\mathrm{w}$ ramach realizacji projektu badawczego [7]. Do dalszych analiz teoretycznych wybrano rozwiązanie według wariantu $4 \mathrm{a}$ przedstawione bardziej szczegółowo na rys. 5 i 6 .
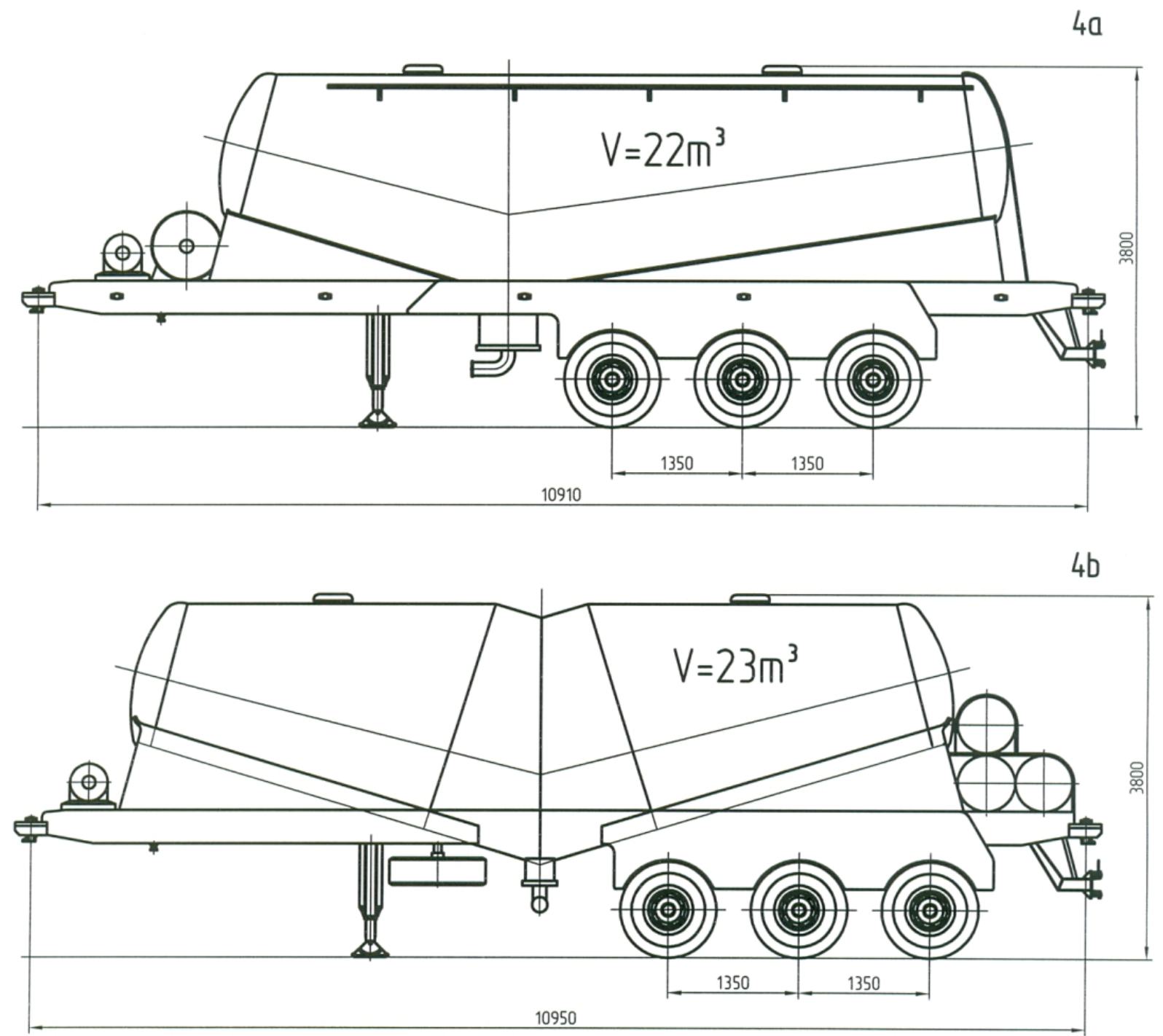

Rys. 4. Naczepy bimodalne do przewozu cementu 


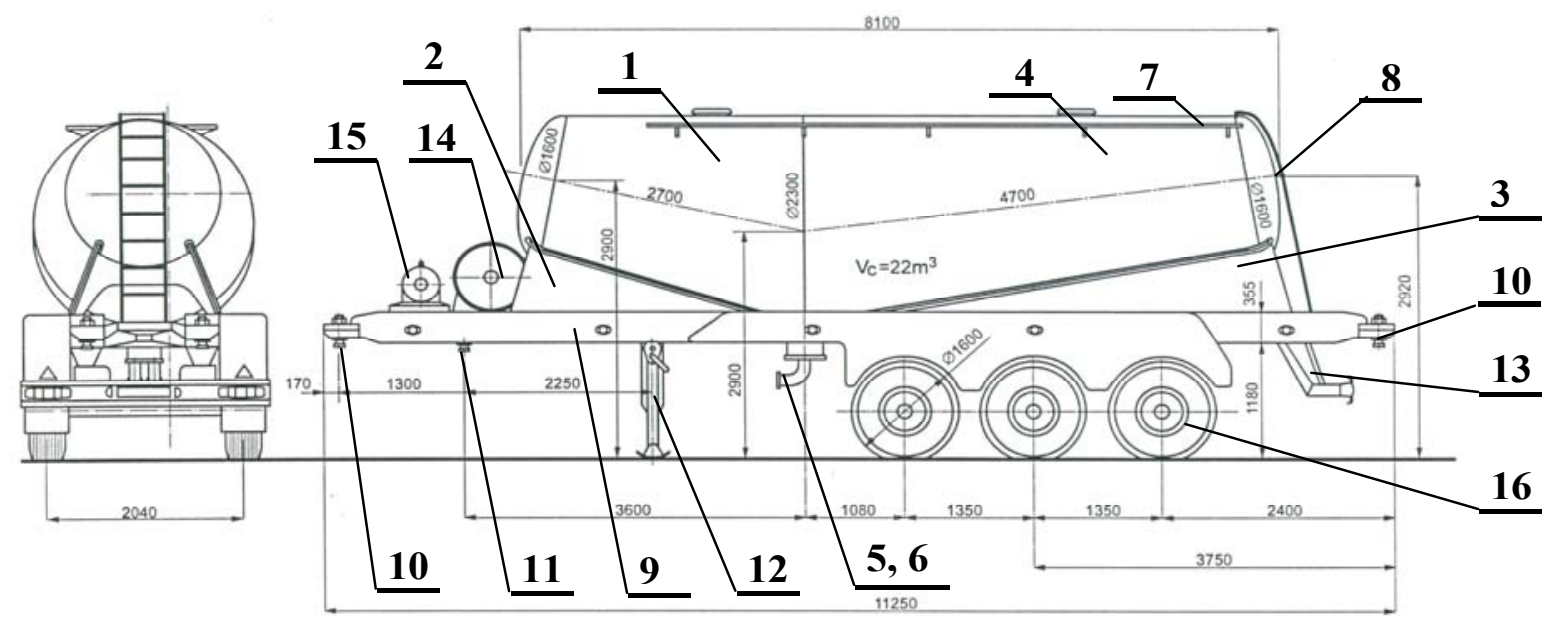

1. Zbiornik 2. Podpora przednia 3. Podpora tylna 4. Właz zasypowy 5. Przewód zsypowy lewy 6. Przewód zsypowy prawy 7. Pomost 8. Drabina wejściowa 9. Rama nośna 10. Czop kolejowy do łączenia z adapterem 11 . Czop drogowy typu JOST 12 . Noga podporowa 13. Odchylny zderzak z tylnymi światłami 14. Zbiornik powietrza 15. Agregat sprężarkowy 16 . Drogowy układ jezdny

Rys. 5. Cysterna bimodalna do przewozu cementu

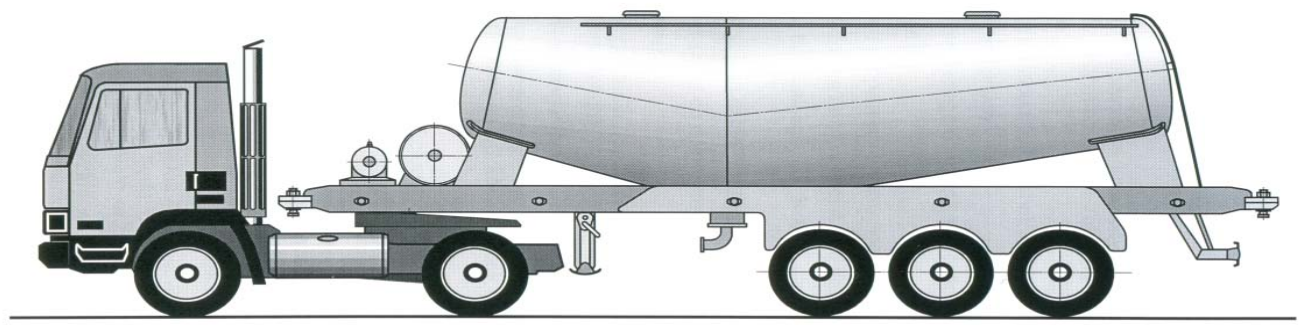

Rys. 6. Cysterna bimodalna z ciagnnikiem siodłowym

Dla wybranego wariantu konstrukcji naczepy ustalono parametry konstrukcyjne oraz wykonano analize wytrzymałości konstrukcji metodą elementów skończonych. Analiza dotyczyła w szczególności obliczeń wytrzymałości zbiornika na podstawie której dobrano grubość ścian poszczególnych segmentów zbiornika przyjmując za kryterium oceny spełnienie warunków wytrzymałości konstrukcji przy minimalnych grubościach blach zbiornika i ramy naczepy.

Przeprowadzona $w$ ten sposób optymalizacja konstrukcji pozwoliła zminimalizować masę zbiornika z ramą do wartości $\sim 4000 \mathrm{~kg}$. Przyjmując, że drogowy układ jezdny wraz z noga podporową oraz innymi urządzeniami ma masę $\sim 3000 \mathrm{~kg}$, łączna masa naczepy bimodalnej do przewozu cementu wynosi $7000 \mathrm{~kg}$. Uzyskana objętość ładunkowa pozwala na załadunek $\sim 22 \mathrm{~m}^{3}$ cementu, co przy ciężarze właściwym cementu $1,8 \mathrm{~g} / \mathrm{cm}^{3}$ daje ladunek o masie $40480 \mathrm{~kg}$.

Zgodnie z obowiązującymi przepisami maksymalna masa naczepy może wynosić 37 ton. Przy masie własnej naczepy $\sim 7$ ton maksymalna ładowność wynosić 30 ton. Zatem objętość ładunkowa zbiornika nie może być maksymalnie wykorzystana.

\subsection{Naczepy do przewozu asfaltu}

$\mathrm{W}$ ramach przeprowadzonych $\mathrm{w}$ Instytucie prac rozwojowych [8] opracowano również koncepcję bimodalnej cysterny izotermicznej do transportu masy asfaltowej lub smoły pogazowej. Bimodalną cysternę izotermiczną zamocowaną na wózkach kolejowych przedstawiono na rys. 7 . Na rys. 8 pokazano trzy warianty rozwiązania podgrzewania przewożonego czynnika chemicznego.

Podgrzewanie ładunku cysterny można zrealizować trzema metodami:

- ogrzewaniem elektrycznym rys. 8 a

- $\quad$ ogrzewaniem parowym wewnętrznym rys. $8 \mathrm{~b}$

- ogrzewaniem parowym lub wodnym rys. $8 \mathrm{c}$

Izolację termiczną cysterny może stanowić wełna mineralna, pianka polistyrenowa lub poliuretanowa. Całą powierzchnię zewnętrzną zbiornika pokrywa się warstwami wełny mineralnej. Grubość izolacji dobiera się dokonując odpowiednich obliczeń cieplnych. Współczynnik przewodzenia ciepła materiałów izolacyjnych winien wynosić $\lambda ? 0,03 \div 0,04$. Izolacja zbiornika może być jednowarstwowa lub wielowarstwowa typu „Sandwich”. Optymalna grubość izolacji wynosi w praktyce około $100 \mathrm{~mm}$, a maksymalnie $200 \mathrm{~mm}$. Materiały izolacyjne oraz technologia ich zastosowania winna zapewnić maksymalny spadek temperatury czynnika $\sim 10^{\circ} \mathrm{C}$ po 100 godzinach upływu czasu od momentu podgrzania czynnika. 

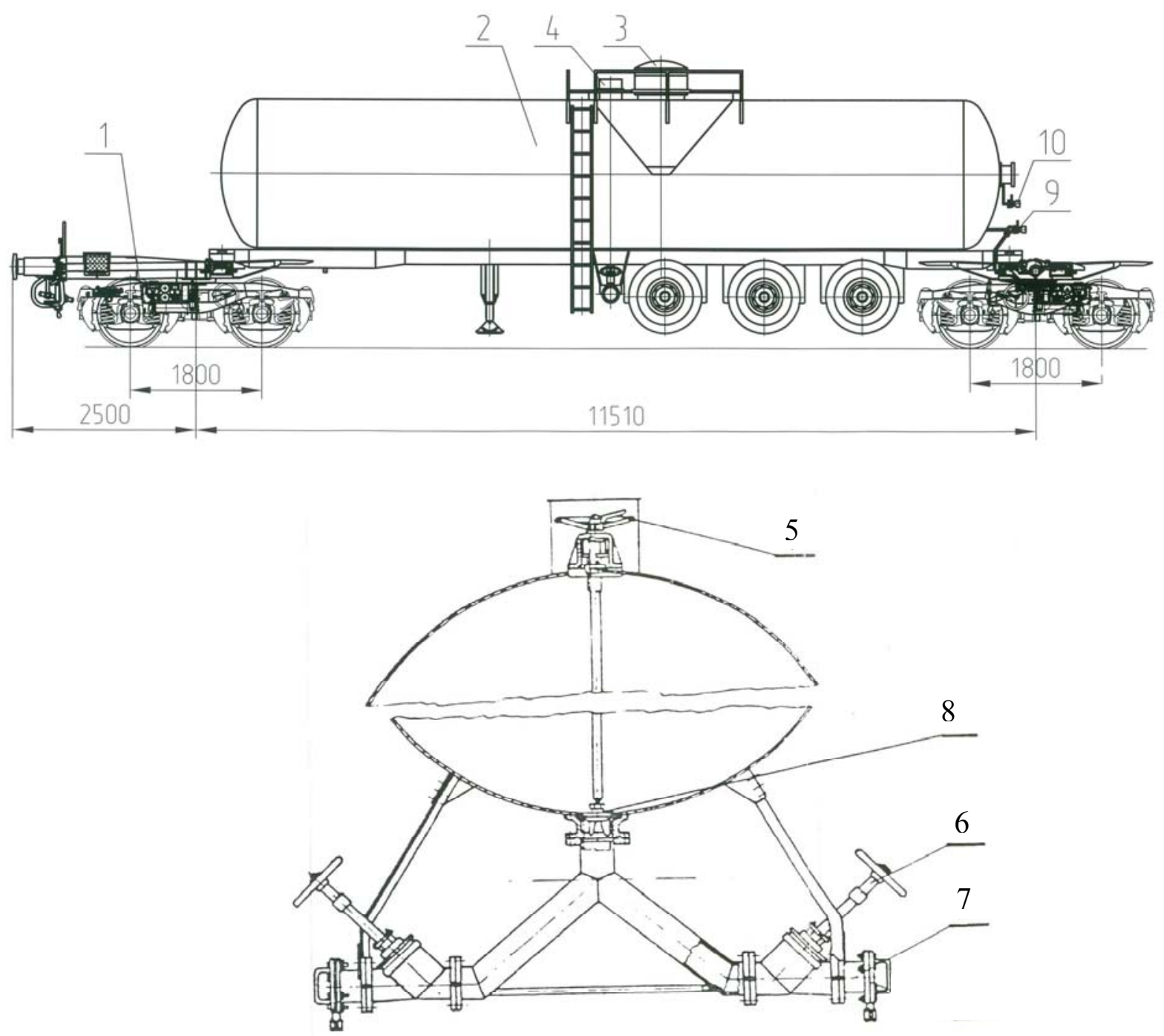

1. Wózek z adapterem 2. Cysterna bimodalna 3. Kołpak armatury napełniająco - opróżniającej 4. Kołpak koła pokrętnego zaworem środkowym 5. Koło do odkręcania zaworu środkowego 6. Zawór boczny 7. Króciec do opróżniania 8. Zawór środkowy 9. Kurek kondensatu 10. Kurek doprowadzający parę

Rys. 7. Cysterna izotermiczna na wózkach kolejowych

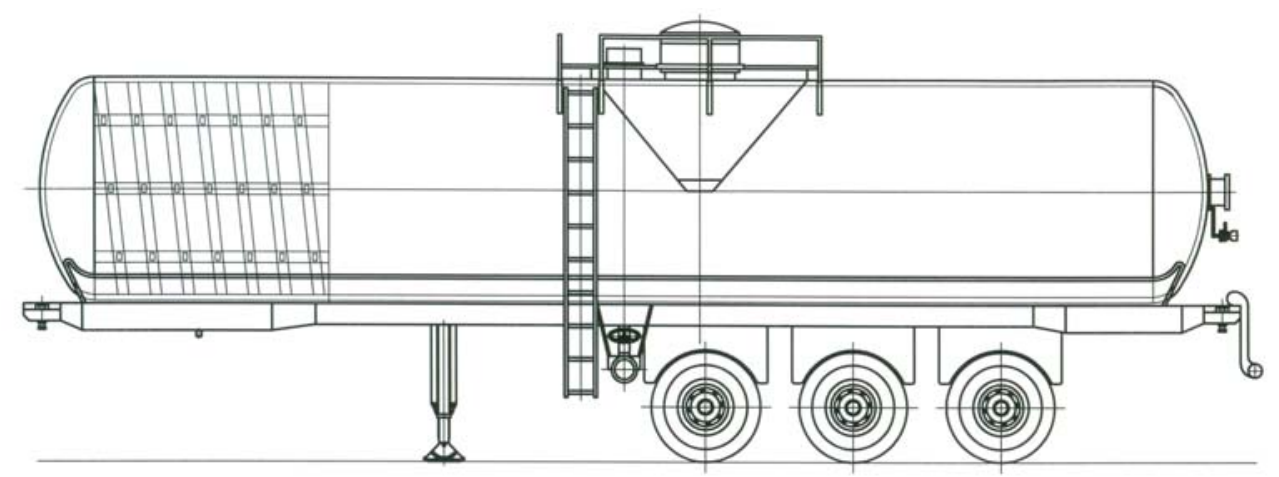

$8 \mathrm{a}$

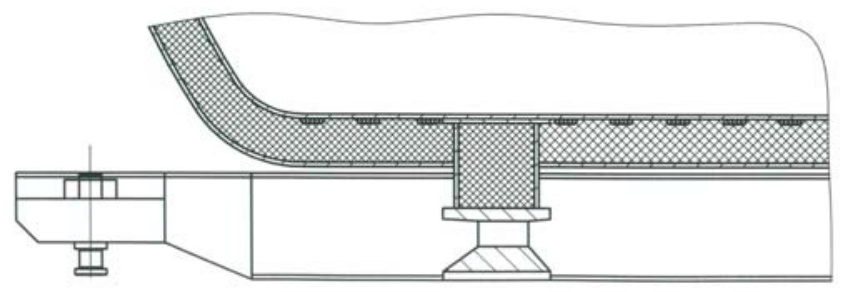



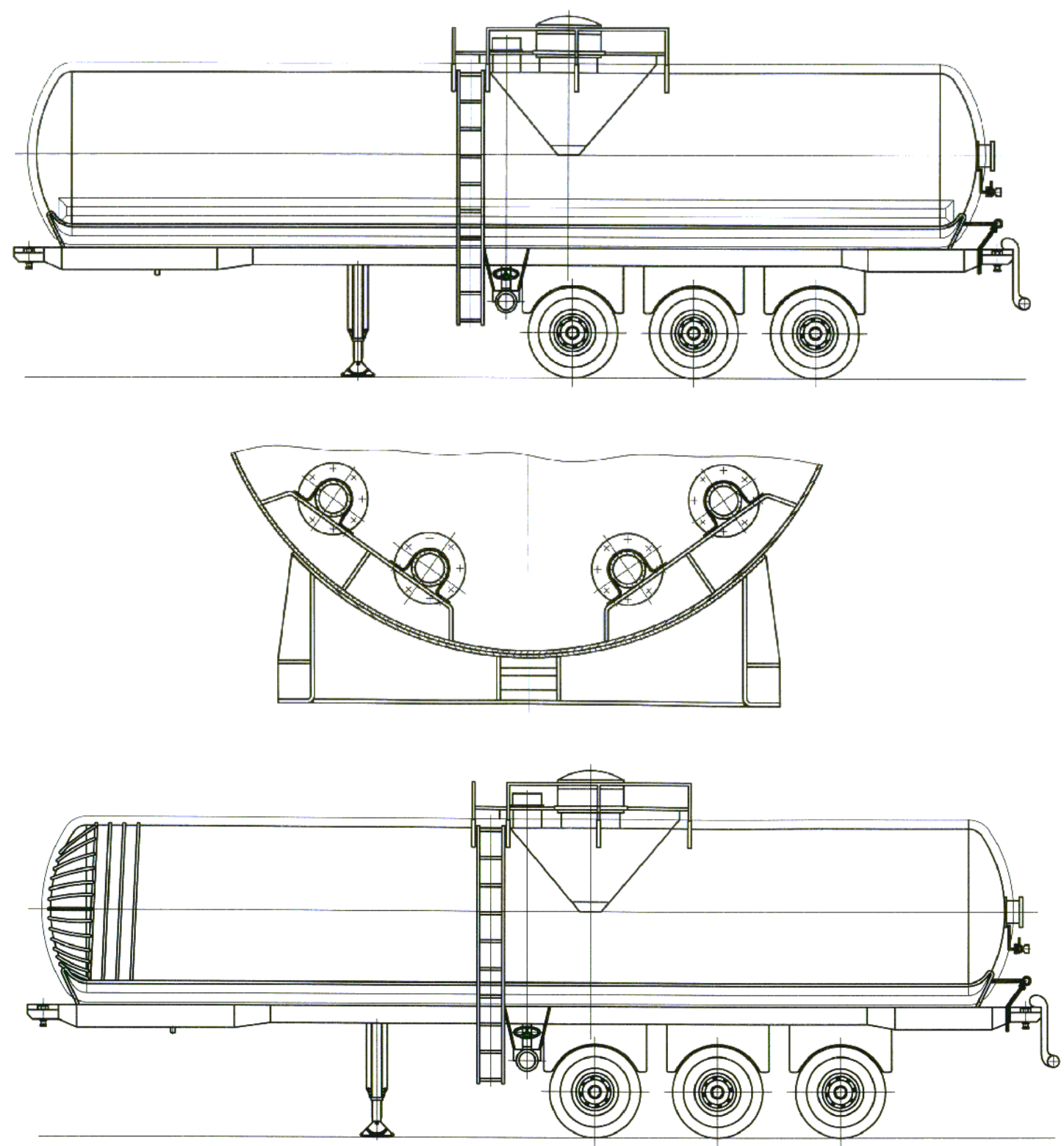

$8 \mathrm{c}$

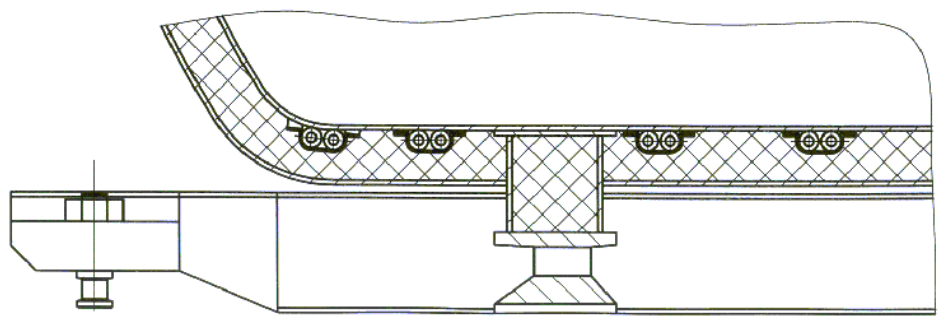

Rys. 8. Bimodalna cysterna izotermiczna

\subsection{Naczepy do przewozu kruszywa}

W planach rozwojowych Instytutu przewiduje się opracowanie koncepcji bimodalnej naczepy wywrotki w oparciu o produkowane naczepy drogowe firmy Wielton, typu NW24, 33 lub 38 (rys. 9).

Adaptacja naczepy drogowej na naczepę bimodalną wymaga opracowania nowej konstrukcji ramy nośnej naczepy z końcami ramy przystosowanymi do zamocowania na adapterach jak również zwężenia rozstawu kół naczepy z 2040 lub $2100 \mathrm{~mm}$ dla naczepy drogowej, na rozstaw $\sim 1940 \mathrm{~mm}$ dla naczepy bimodalnej. Ponad to naczepę należy wyposażyć w inne urządzenia niezbędne do eksploatacji w ruchu kolejowym.

Na rys.10 przedstawiano propozycję koncepcji naczepy bimodalnej a rys.11 przedstawia naczepę wywrotkę na wózkach kolejowych. 

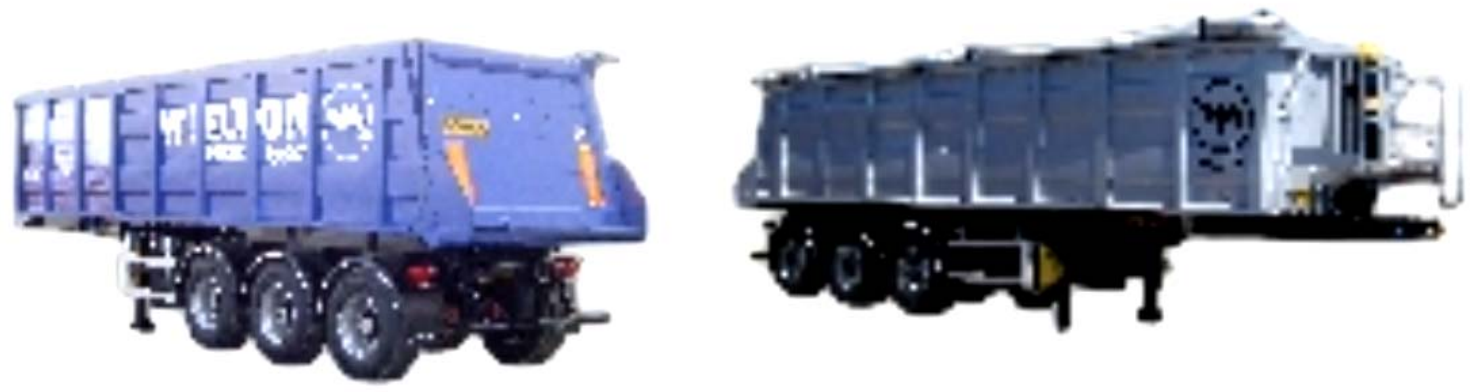

Rys. 9. Naczepa drogowa firmy WIELTON

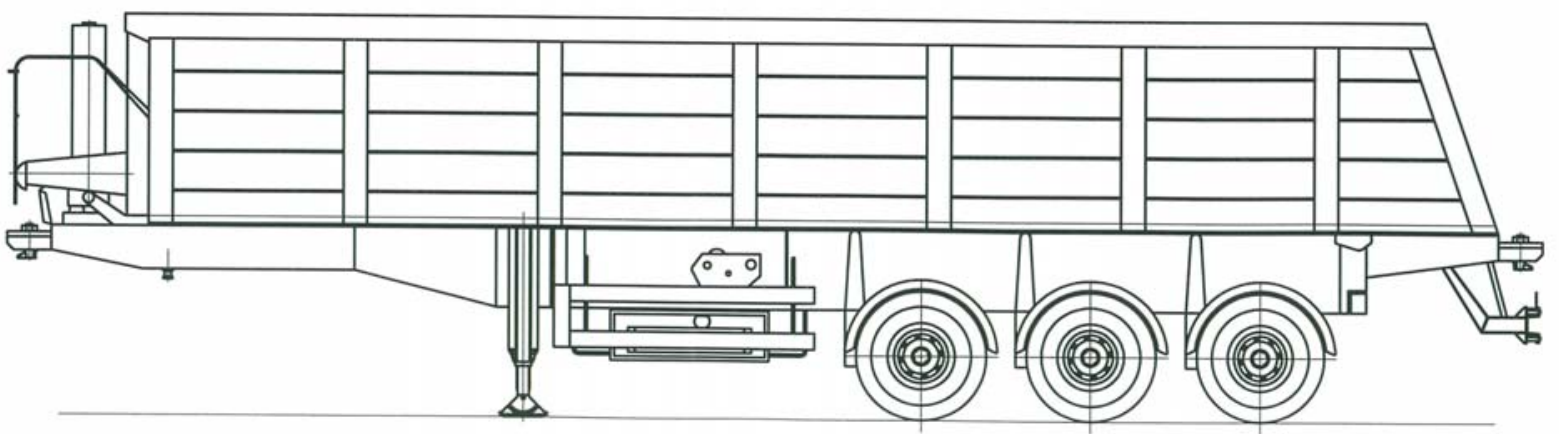

Rys. 10. Koncepcja naczepy bimodalnej do przewozu kruszyw

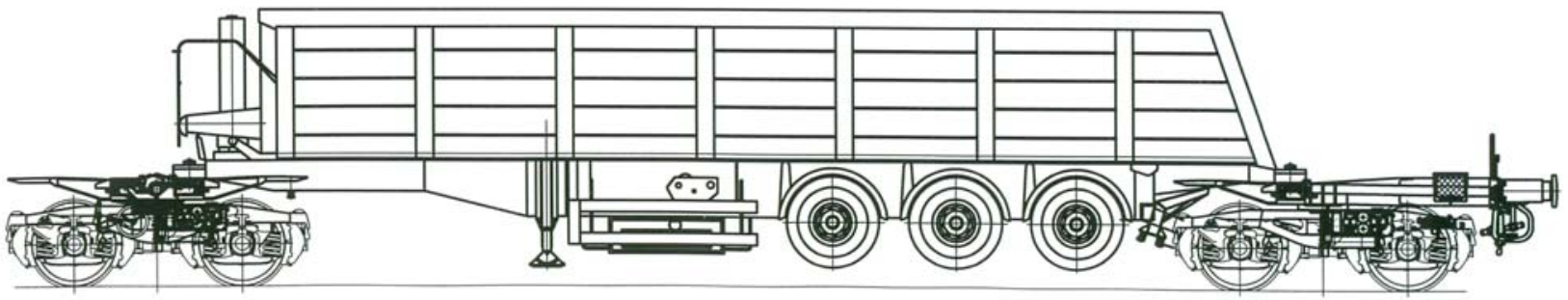

Rys. 11. Naczepa bimodalna na wózkach kolejowych

\section{Wykorzystanie techniki bimodalnej do trans- portu materiałów budowlanych}

Podstawowe materiały budowlane używane $\mathrm{w}$ inwestycjach drogowych to: piasek, cement, kruszywa i asfalt. Do budowy autostrad i dróg szybkiego ruchu zużywa się duże ilości wymienionych materiałów. Dowóz materiałów na plac budowy wymaga użycia dużej ilości samochodów ciężarowych o dużej ładowności. Technika bimodalna umożliwia dostarczenie na plac budowy jednorazowo znacznej ilości materiałów budowlanych. Skład pociagu bimodalnego zgodnie z przepisami może być złożony z naczep w ilości maksymalnej 50-ciu naczep w składzie pociagu. Zakładając średnio ładowność naczepy bimodalnej $\sim 27$ ton, na plac budowy można dostarczyć jedncześnie ładunek o masie $50 \times 27$ ton, to jest 1350 ton.
Technika bimodalna jest proekologiczna oraz energooszczędna i ekonomiczna $\mathrm{w}$ porównaniu $\mathrm{z}$ transportem drogowym. W Polsce jest około 4000 bocznic kolejowych, często nieużywanych, z których część można wykorzystać na terminale przeładunkowe. Muszą być one zlokalizowane w niedużej odległości od trasy budowy autostrady (do $50 \mathrm{~km}$ ). Logistyka organizacji transportu bimodalnego zakłada przewóz materiałów na duże odległości z wykorzystaniem transportu kolejowego, a małe odległości transportem drogowych (dowóz towaru od dostawcy do terminalu załadowczego i z terminalu wyładowczego do odbiorcy rys 12 .

Dostawcy materiałów budowlanych są $\mathrm{z}$ reguły usytuowani w dużych odległościach od trasy budowy autostrady. Organizację dostaw materiałów od producentów na plac budowy można zaplanować w sposób przedstawiony na rys. 13a lub $13 \mathrm{~b}$. 


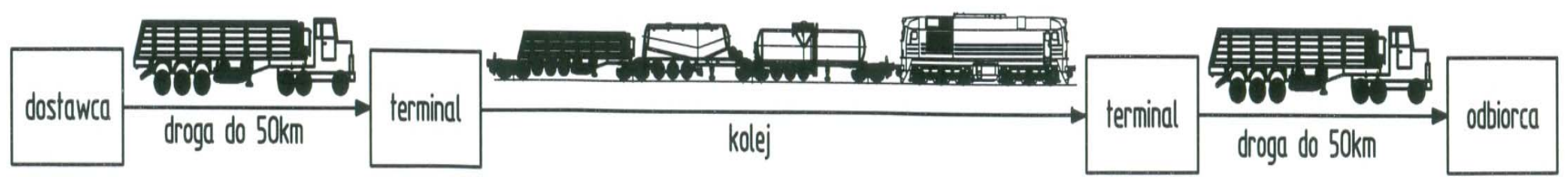

Rys. 12. Zasada funkcjonowania transportu bimodalnego

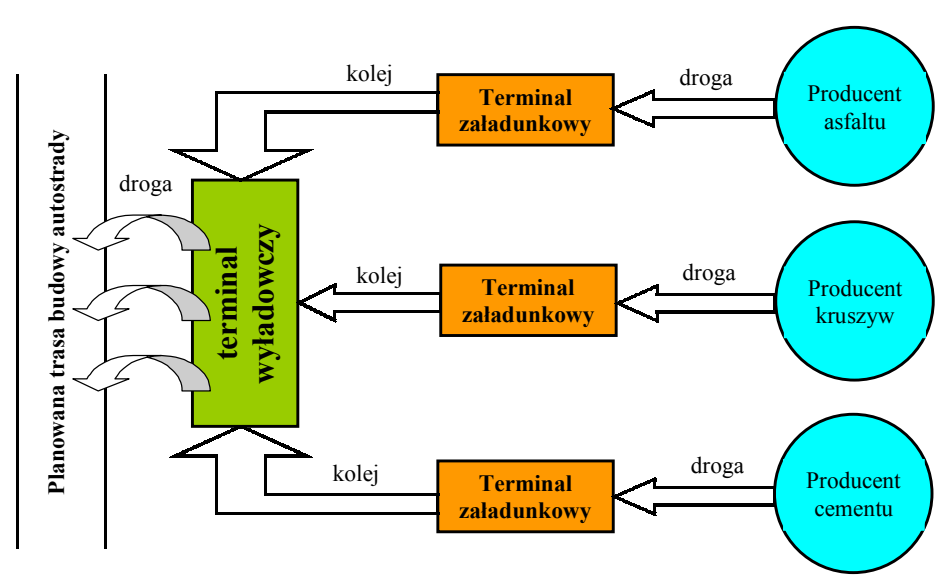

Rys. 13a. Przykładowy system dostaw towarów na plac budowy (wariant 1)

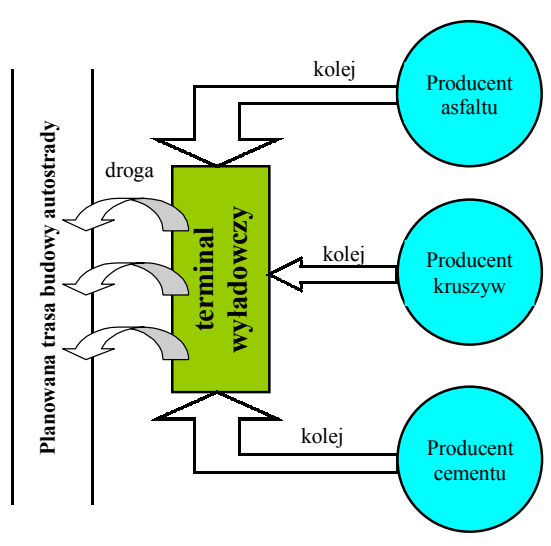

Rys. 13b. Przykładowy system dostaw towarów na plac budowy (wariant 2)
Wykorzystanie systemu bimodalnego do budowy autostrad może w znaczny sposób wpłynąć na wybór dostawców cementu i asfaltu, nawet $z$ większych jak do tej pory odległości, natomiast $\mathrm{w}$ przypadku transportu kruszyw może mieć kluczowe znaczenie i to głównie na ich transporcie PKP mogłoby znakomicie zarabiać. Materiały do budowy autostrad nie występują bowiem w Polsce w sposób równomierny. Zasoby te można podzielić zarówno pod względem ilościowym jak i jakościowym. Południe Polski (rejon Karpacko - Sudecki) posiada około $60 \%$ zasobów z których główna część to kruszywa łamane i wysokiej jakości piaszczysto żwirowe. Polska centralna posiada zaledwie $10 \%$ ogólnego zasobu kruszyw, a w dodatku są to głównie wapienie o ograniczonym zastosowaniu oraz małe i złej jakości kruszywa piaszczysto żwirowe. Pozostałe $30 \%$ przypada na Polskę północna, gdzie głównie występują kruszywa piaszczysto żwirowe. Dużym zainteresowaniem cieszą się również występujące regionalnie polodowcowe narzutniaki, głazy i otoczaki dające dobrej jakości kruszywo łamane.

Istotną część materiałów do budowy autostrad stanowią również wszelkiego rodzaju odpady górnicze, hutnicze, popioły z elektrowni oraz wszelkiego rodzaje pyły z elektrowni. Tak zróżnicowana możliwość dostarczania materiałów, ze względu na ich występowanie lub pochodzenie, powoduje konieczność ich transportu na znaczne odległości.

Z uwagi na dużą ilość istniejących w Polsce bocznic kolejowych istnieje duże prawdopodobieństwo zlokalizowania bocznic w pobliżu planowanej trasy budowy autostrady. Na etapie planowania budowy należy dokonać rozpoznania istniejących bocznic kolejowych, które można wykorzystać na „wędrujący terminal" wzdłuż budowanej autostrady.

Stworzenie terminalu przeładunkowego z bocznicy kolejowej nie wymaga dużych nakładów inwestycyjnych. Adaptacja bocznicy na terminal sprowadza się do wyłożenia odpowiedniej długości torowiska płytami betonowymi aby wyrównać poziom terenu z poziomem toru. Wielkość terminalu wyznaczona jest wymaganą przestrzenią do manewrowania ciagnika siodłowego $\mathrm{w}$ procesie formowania i rozformowania składu pociagu bimodalnego. Na rys. 14 przedstawiono zasadę tworzenia „wędrującego terminalu” przeładunkowego wzdłuż trasy budowanej autostrady. 


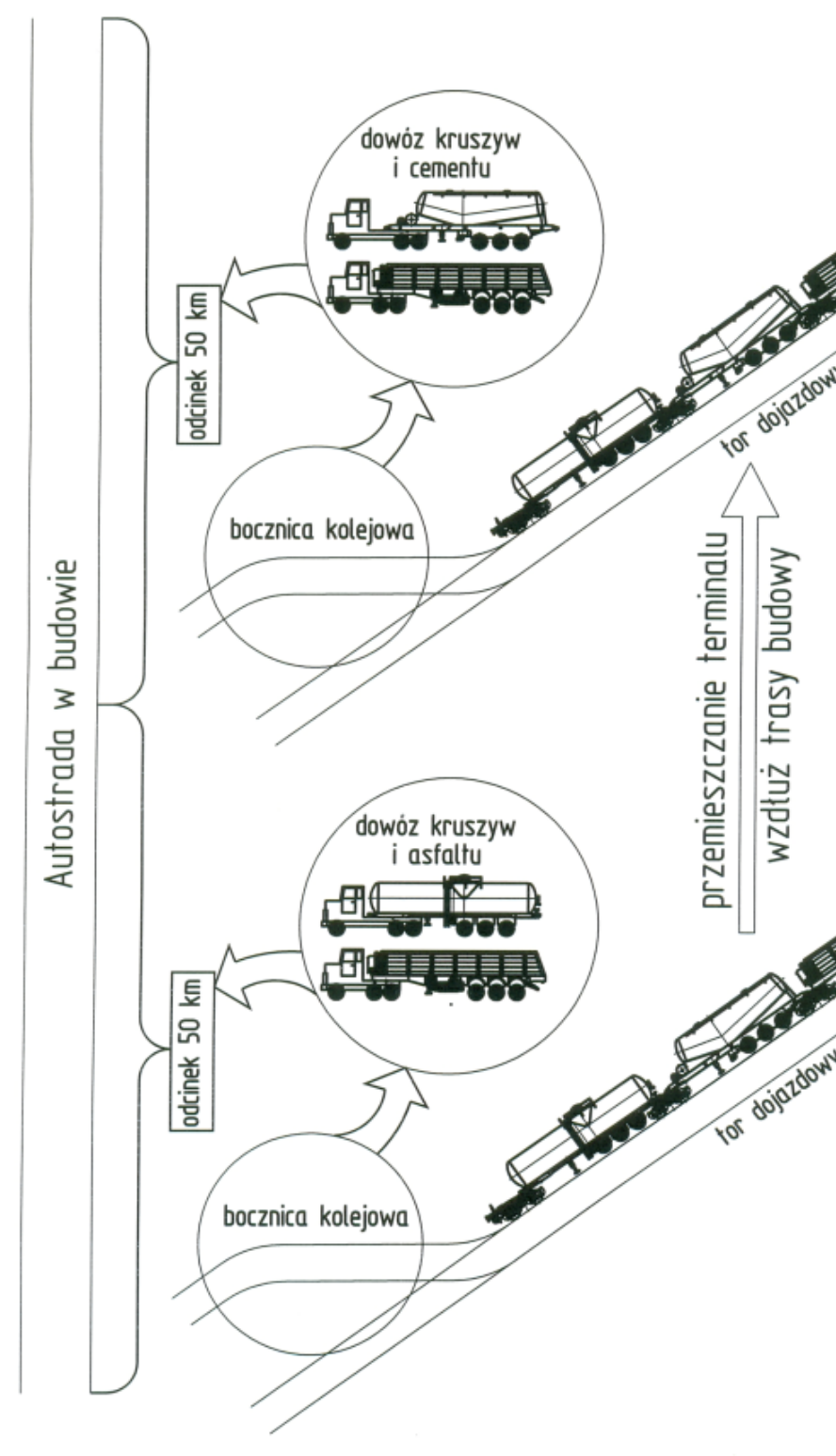

\section{Podsumowanie}

Wybór kolei klasycznej jako środka transportu generuje jeszcze tą trudność, że istnieje konieczność przeładunku towarów z kolei na środki transportu drogowego. Istnieje również konieczność zabezpieczenia placów składowych (magazynowych), na których dostarczone materiały będa przechowywane do czasu załadowania go na pojazdy samochodowe. Takie czynniki powodują, że istnieje konieczność stosowania specjalnych urządzeń do przeładunku, oraz wykorzystania tylko niektórych terminali, dysponujących odpowiednią infrastrukturą i odpowiednim zapleczem logistyczno - magazynowym. Dowóz materiałów z zastosowaniem nowoczesnej techniki bimodalnej jest pozbawiony tych wad. Towar ładowany na naczepy u producenta dostarczany i rozładowany jest bezpośrednio na placu budowy. Terminal, a w szczególności „terminal wędrujący” nie wymagają skomplikowanej infrastruktury. $Z$ tego też powodu istnieje możliwość łatwego dostosowania większości terminali i bocznic kolejowych do obsługi pojazdów pracujących w systemie bimodalnym.

Artykuł adresowany jest do projektantów i budowniczych dróg i autostrad jak również do PKP Cargo i innych przewoźników jako propozycja wykorzystania innowacyjnej technologii dostarczania materiałów budowlanych na tereny budowy autostrad. Wykorzystanie proponowanej metody wymaga opracowania analiz logistycznych i ekonomicznych przez specjalistów z dziedziny prowadzenia inwestycji drogowych i analityków ruchu kolejowego.

\section{Literatura:}

1. Konferencja: „Kruszywa: mity i rzeczywistośc” 08.10.2008 Sosnowiec, organizator Sejmowa Komisja Infrastruktury.

2. Kłopoty kolei ogranicza budowe autostrad, Gazeta Wyborcza 22.04 .09 (www.wnp.pl).

3. Skandal! Dlaczego na Euro 2012 nie będzie autostrad, www.auto-swiat.pl.

4. Baj L., Wielgo M.: Podwyzki W PKP CARGO zaszkodza droga, Gazeta Wyborcza 01.07.07.

5. Medwid M., Cichy R.: Analiza porównawcza wybranych systemów transportu intermodalnego, Pojazdy Szynowe 1/2009.

6. Medwid M.: Polski system transportu kolejowo drogowego [bimodalnego] typu ,TABOR”, Wydawnictwo IPS TABOR, Poznań 2006.

7. Medwid M.: Ksztattowanie postaci pojazdu zbiornika do transportu cementu luzem w systemie bimodalnym, drogowo - kolejowym. Projekt badawczy $\mathrm{nr}$ 9T12C01216. Sprawozdanie merytorczne. Poznań 2000.

8. Medwid M., Nowotarski P., Marciniak Z.: Możliwość zastosowania technologii typu „Sandwich” $w$ konstrukcji pudła wagonów izotermicznych, szczególności cystern bimodalnych. Opracowanie IPS TABOR. Poznań 1994. 